\title{
Alat Pengering Kerupuk untuk Meningkatkan Usaha Kecil Industri Rumah Tangga di Desa Mulyoagung, Kecamatan Dau, Kabupaten Malang
}

\author{
Unung Lesmanah \\ Universitas Islam Malang
}

\author{
M. Jasa Afroni \\ Universitas Islam Malang
}

\author{
Abdul Wafi \\ Universitas Islam Malang
}

\begin{abstract}
This community service activity is carried out to find solutions to the problems of partners who have difficulty drying Puli crackers in cloudy/rainy weather conditions. The drying oven designed by the activity implementation team can help the drying process in conditions of sunlight that do not support optimal drying. By using a drying oven, the productivity of Puli crackers during cloudy or rainy weather increased by about $200 \%$ compared to the production of crackers without using an oven. This designed oven uses gas fuel with a fairly simple technology so that it is easy for partners to operate.
\end{abstract}

Keywords: Crackers; Drying oven; Productivity

\begin{abstract}
Abstrak
Kegiatan pengabdian masyarakat ini dilakukan untuk mencarikan solusi bagi permasalahan mitra yang mengalami kesulitan untuk mengeringkan kerupuk puli dalam kondisi cuaca mendung / hujan. Oven pengering yang dirancang oleh team pelaksana kegiatan dapat membantu proses pengeringan dalam kondisi sinar matahari yang yang kurang mendukung pengeringan yang optimal. Dengan menggunakan oven pengering, produktivitas kerupuk puli selama cuaca mendung atau hujan meningkat sekitar $200 \%$ dibandingkan dengan produksi kerupuk tanpa menggunakan oven. Oven hasil rancangan ini menggunakan bahan bakar gas dengan teknologi yang cukup sederhana sehingga mudah dioperasikan oleh mitra.
\end{abstract}

Kata Kunci: Kerupuk; Oven pengering; Produktivitas

\section{Pendahuluan}

Masyarakat Indonesia telah lama mengenal kerupuk sebagai makanan kecil. Jenis makanan ini pada umumnya di konsumsi sebagai makanan yang mampu membangkitkan selera makan atau sekedar dikonsumsi sebagai makanan kecil banyak jenis kerupuk dibuat orang, mulai dari kerupuk yang dibuat dari beras, tepung terigu, ataupun dari tepun tapioca. Pembuatan aneka kerupuk tidak memerlukan keterampilan khusus sehingga dapat dilakukan sebagai industry rumah tangga [1].

Desa Mulyoagung adalah sebuah desa di Dataran Tinggi yang terletak di Kecamatan Dau, Kabupaten Malang yang terdiri dari 5 dusun, yaitu Jetis, Sengkaling, Dermo, Jetak Lor, dan Jetak Ngasri. Sebagian besar penduduk Desa Mulyoagung bekerja sebagai Petani, Peternak, Guru, Dosen, ASN, Wiraswasta, dan Pedagang.

Di antara kegiatan wiraswasta tersebut, terdapat beberapa usaha pembuatan berbagai macam kerupuk skala kecil yang dilakukan oleh industri rumah tangga. Di antara berbagai 
kerupuk yang diproduksi, Kerupuk puli termasuk jenis yang cukup digemari oleh masyarakat. Kerupuk puli merupakan olahan kerupuk yang dibuat dengan menggunakan bahan baku tepung tapioca diramu dengan bahan bahan tambahan. Garam bleng merupakan bentuk tidak murni dari boraks yang biasa digunakan pada pembuatan krupuk, dimana berfungsi supaya kerupuk tidak mudah patah, adonan menjadi kenyal, dan agar kerupuk bisa mengembang tapi dalam penggunaannya harus sesuai dengan komposisi [2] .

Kerupuk jenis ini proses pembuatannya sangat mudah dan biaya pembuatannya juga murah, sehingga sering diproduksi oleh industri rumah tangga, seperti usaha kecil pembuatan kerupuk puli milik ibu Mi'atun. Usaha milik mitra ini menyerap tenaga kerja sejumlah 3 sampai 6 orang. Usaha ini cukup berkembang dan kerupuk puli hasil produksi ibu Mi'ah cukup digemari yang terlihat dari permintaan masyarakat di warung-warung yang dititipi kerupuk puli tersebut cukup tinggi [3]. Permintaan yang besar itu sering kali tidak dapat dipenuhi karena kapasitas produksi yang kurang memadai. Selain masalah kapasitas produksi yang rendah, pembuatan kerupuk pada usaha mikro ini masih dilakukan secara konvensional yang menimbulkan persoalan pada hasil produksi kerupuk yang kurang higienis [4].

Rendahnya kapasitas produksi yang dihadapi oleh usaha mikro ini antara lain dikarenakan penjemuran krecek kerupuk (kerupuk mentah) masih mengandalkan sinar matahari. Cuaca di berbagai daerah di Indonesia kadang-kadang mengalami anomali, misal terjadinya hujan lebat di bulan-bulan musim kemarau (Sirait, 2016). [5] Ketika terjadi cuaca mendung maka proses penjemuran tidak berlangsung dengan baik dan krecek kerupuk tidak cukup kering untuk digoreng, sehingga harus dijemur lagi pada hari berikutnya. Bahkan apabila terjadi cuaca hujan beberapa hari, maka pengeringan kerupuk dapat mengalami kegagalan dan kerupuk yang lembab akan ditumbuhi jamur.

Perancangan dan pembuatan alat pengering ini perlu dilakukan sedemikian rupa sehingga produk ini dapat menjawab pertanyaan desain produk sebagai berikut: (a) Apakah produk ini membantu memenuhi kebutuhan manusia? (b) Apakah produk mampu bersaing di pasar? (c) Apakah produk ekonomis untuk diproduksi? dan (d) Apakah produk akan menguntungkan bila dijual? [6]

Salah satu proses dalam produksi krupuk adalah proses pengeringan, Proses pengeringan yang dilakukan kebanyakan oleh masyarakat masih secara konvensional, yaitu pengeringan dilakukan di tempat terbuka yang bergantung dari sinar matahari. Dalam pengeringan konvensional terdapatbeberapa permasalahan yaitu panas yang fluktuatif, kebersihan yang tidak terjaga dan memerlukan tempat yang cukup luas.Mengingat di Indonesia terdapat dua musim yaitu musim kemarau dan penghujan, maka salah satu hal yang menjadi kendala dalam produksi kerupuk adalah proses pengeringan disaat musim penghujan. Dimana panas yang dibutuhkan dalam proses pengeringan tidak bisa terus menerus ada karena adanya hujan [7].

Pembuatan pengering kerupuk tersebut akan dilanjutkan dengan pelatihan penggunaan alat tersebut kepada mitra, diharapkan bahwa produksi kerupuk dapat ditingkatkan untuk memenuhi permintaan masyarakat, Sehingga pendapatan bagi pemilik dan karyawan usaha mikro pembuatan kerupuk akan bertambah.

\section{Metode Pelaksanaan}

Kegiatan pengabdian masyarakat ini dilaksanakan oleh team dari Fakultas Teknik dan Fakultas Agama Islam Universitas Islam Malang. Adapun mitra kegiatan yaitu ibu Mi'atun pemilik usaha mikro pembuatan kerupuk. Dalam pelaksanaannya, kegiatan ini dilakukan dengan tahap-tahap sebagai berikut. (1) Koordinasi dan diskusi antar anggota tim dengan mitra. Hal ini dimaksudkan untuk mendapatkan masukan dan gagasan yang digunakan untuk implementasi program ini. Penyamaan persepsi dan langkah gerak dalam pelaksanaan program ini menjadi penting dengan cara kerja yang kolegial seluruh anggota tim dan mitra; (2) Merancang dan 
membuat alat pengering untuk penunjang peningkatan produksi kerupuk puli; (3) Memberikan pelatihan cara penggunaan alat pengering kerupuk; dan (4) Serah terima alat pengering krupuk.

Pembuatan alat pengering kerupuk bertenaga gas dilakukan dalam jangka waktu 3 bulan, yang dilaksanakan di laboratorium Fakultas Teknik, Universitas Islam Malang dan bekerja sama dengan bengkel milik masyarakat setempat [8]. Kegiatan ini meliputi perancangan alat, pembuatan alat, uji coba dan penyempurnaan alat. Setelah uji coba alat menunjukkan hasil yang memadai dan alat siap digunakan, maka dilakukan serah terima alat kepada mitra dan dilanjutkan dengan kegiatan training (pelatihan) penggunaan alat pengering kerupuk oleh tim pelaksana kegiatan.

Dari hasil diskusi tim pelaksana, alat pengering yang akan dibuat adalah seperti pada Gambar 1 berikut ini.

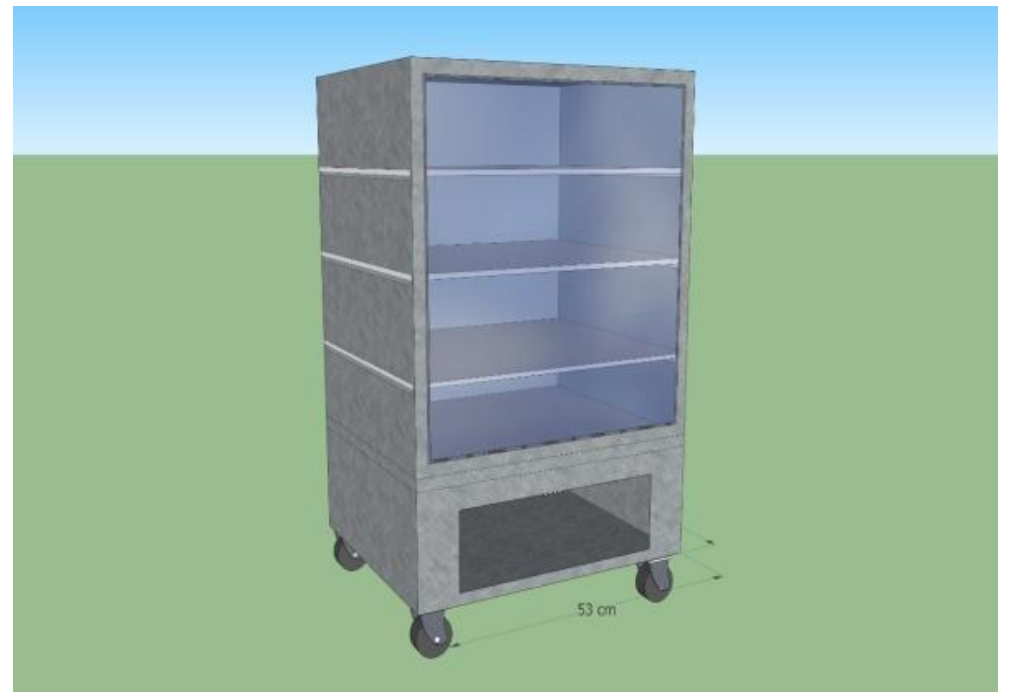

Gambar 1. Desain Alat Pengering

Pengering (oven) yang modern saat ini sudah menggunakan tenaga listrik dengan sistem kontrol otomatis yang canggih. Namun pemanasan menggunakan listrik menjadikan biaya operasi alat menjadi cukup mahal, sehingga tidak sesuai untuk industri kecil pembuatan kerupuk milik mitra [9].

Bahan bakar bio massa merupakan alternative lain untuk mengoperasikan pengering kerupuk yang dirancang. Pengering dengan bahan bakar bio massa dapat menggunakan ketel uap untuk memanaskan air sehingga diperoleh uap air yang suhunya super tinggi. Uap ini dapat digunakan untuk memanaskan ruang pengering kerupuk. [10] Namun karena pertimbangan rumitnya operasional ketel uap, maka alternatif ini tidak dipilih dalam rancangan oven pengering kerupuk ini.

Permasalahan yang dihadapi oleh mitra adalah mengenai pengeringan kerupuk ketika musim penghujan, karena ketika musim penghujan kerupuk tidak lekas kering karena kurangnya sinar matahari ketika proses penjemuran. Produksi menjadi berkurang, padahal permintaan pasar akan kerupuk puli stabil [11].

Program pengabdian masyarakat ini mengusulkan solusi terhadap permasalahan rendahnya kapasitas produksi di atas dengan merancang alat pengering kerupuk yang ekonomis dengan tenaga gas yang dapat dioperasikan dengan mudah. Dengan adanya alat ini, diharapkan proses pengeringan kerupuk dapat dilakukan setiap saat, walaupun cuaca mendung, hujan lebat atau bahkan pada saat malam hari, proses pengeringan tetap dapat berjalan [12]. 


\section{Hasil dan Pembahasan}

Alat yang telah dibuat dapat dilihat pada Gambar 2. Alat pengering ini terbuat dari plat stainless steel, menggunakan kompor gas (1) dengan spuyer tunggal untuk pemanas. Alat ini memiliki pintu (2) yang dilengkapi engsel supaya mudah dibuka dan selama pemanasan alat perlu dikunci menggunakan Grendel yang menyatu dengan pintu. Pintu tersebut dilengkapi kaca supaya memudahkan untuk memeriksa tingkat kekeringan krecek krupuk. Di bagian dalam alat terdapat beberapa loyang (3) yang tersusun ke atas. Krecek yang dikeringkan diletakkan di atas loyang ini. Pada dinding atas alat pengering terdapat lubang (4) untuk melepaskan uap air yang dihasilkan selama proses pengeringan.[13]

Sebelum alat diserahkan kepada mitra, dilakukan uji coba untuk mengetahui unjuk kerjanya. Pada uji coba pengeringan kerupuk tahap pertama, diperoleh hasil yang kurang baik dan masih terjadi kelembaban udara (uap air) pada dinding plat stainless steel bagian atas alat. Selanjutnya, alat disempurnakan dengan menambah lubang pelepas uap air yang disatukan dengan plat tersebut. Uji coba berikutnya ternyata menghasilkan pengeringan yang baik.

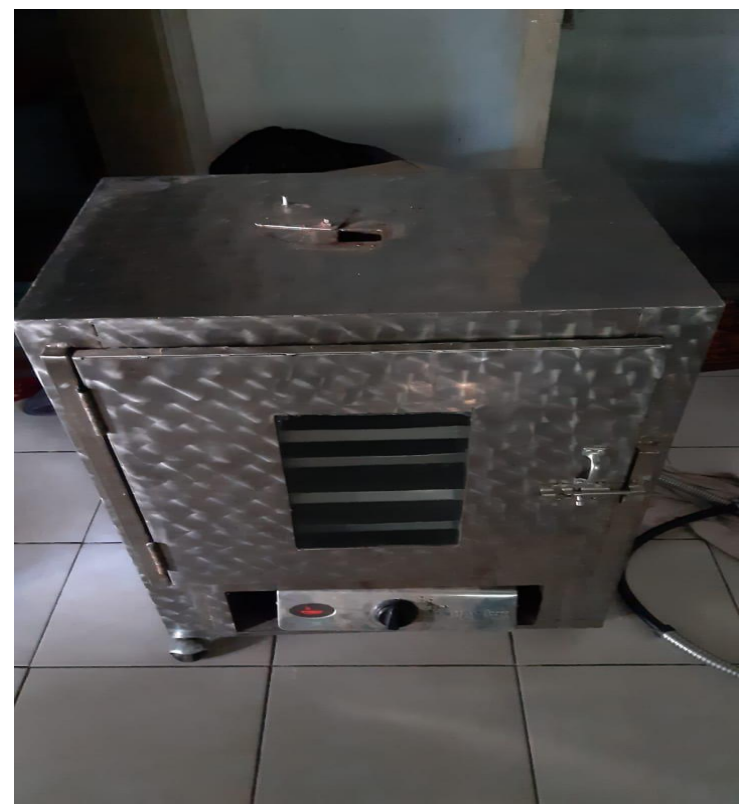

Gambar 2. Alat Pengering kerupuk

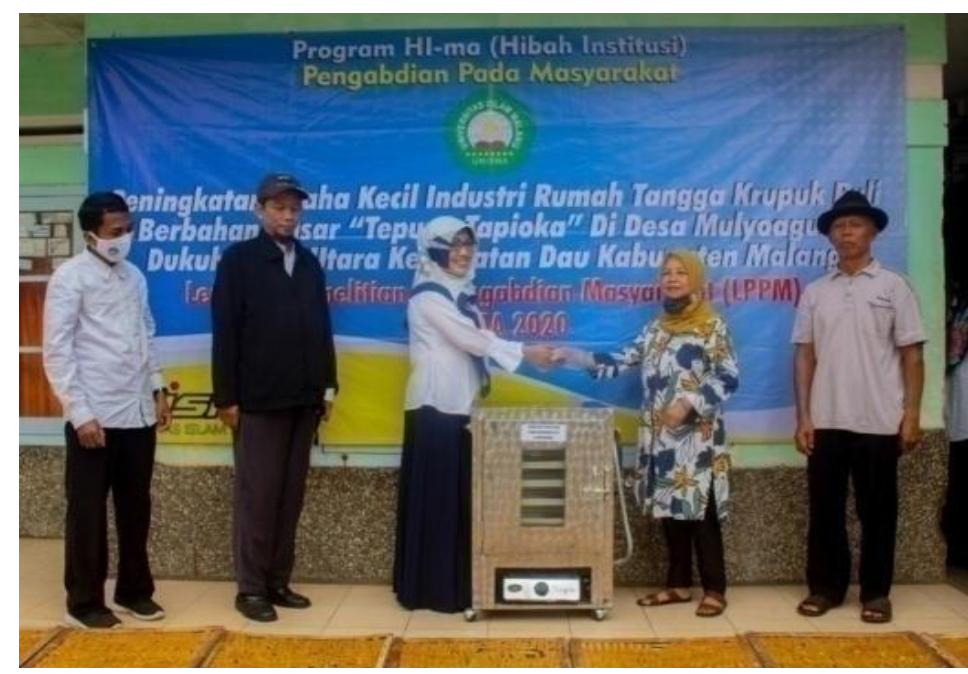

Gambar 3. Serah Terima Alat Pengering Kerupuk 


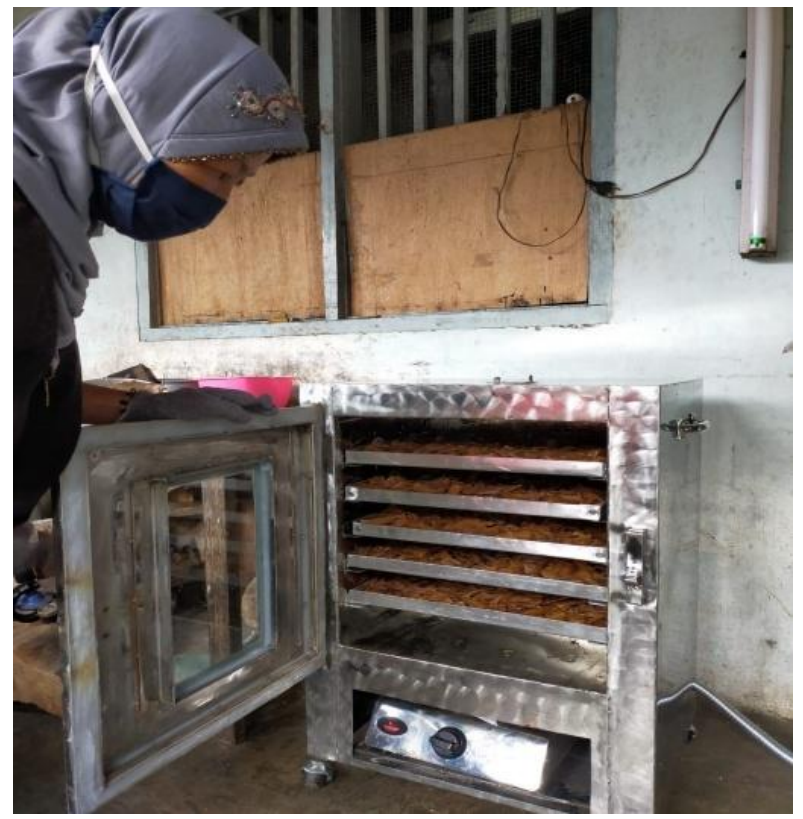

Gambar 4. Penggunaan Alat Pengering Kerupuk

Setelah beberapa kali uji coba, cara penggunaan oven pengering yang disarankan yakni: dalam kondisi tidak ada sinar matahari sama sekali untuk menjemur kerupuk, maka kerupuk mentah yang masih basah bisa diangin-anginkan selama 2 hari, kemudian dikeringkan dengan oven selama 15 menit, dan bisa langsung digoreng [14]. Apabila ada sinar matahari yang cukup untuk menjemur kerupuk, maka kerupuk yang sudah dijemur selama 1 hari bisa dikeringkan lebih lanjut menggunakan oven selama 15 menit, langsung bisa digoreng. Apabila tidak menggunakan oven, kerupuk perlu dikeringkan lagi sebentar di bawah sinar matahari di hari kedua, baru bisa digoreng. Tampilan fisik kerupuk yang dikeringkan menggunakan oven tidak jauh berbeda dengan kerupuk yang dikeringkan secara konvensional menggunakan sinar matahari, seperti ditunjukkan pada Gambar 5.

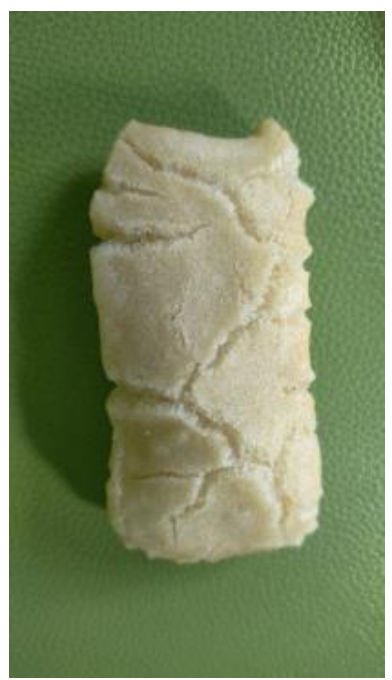

(a)

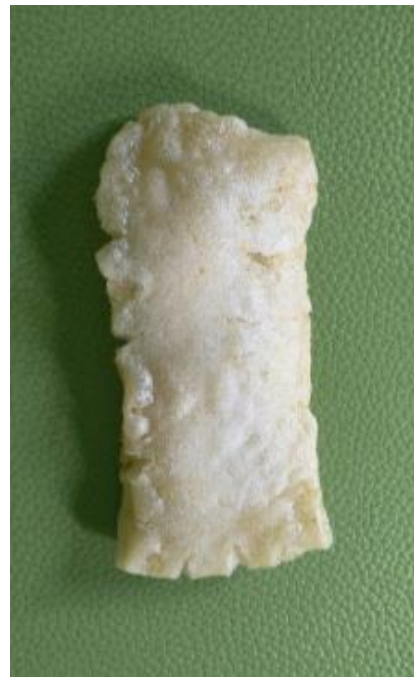

(b)

Gambar 5. (a) Kerupuk yang dikeringkan menggunakan sinar matahari (b) Kerupuk yang dikeringkan menggunakan oven pengering

Kapasitas alat ini sekali proses pengeringan sebanyak $6 \mathrm{~kg}$ krecek (kerupuk mentah). Biaya operasional alat ini juga cukup ekonomis, karena satu tabung gas $3 \mathrm{~kg}$ (tabung melon) bisa 
digunakan untuk rata-rata 3 kali pengeringan. Dari informasi mitra, harga produksi kerupuk yang dikeringkan menggunakan alat ini masih wajar dan tidak mempengaruhi harga jual kerupuk ke konsumen.

Dengan menggunakan oven pengering ini, diperoleh peningkatan produktivitas usaha kerupuk milik mitra, yang dapat dilihat pada Tabel 1.

Tabel 1. Perbandingan Produktivitas Usaha Kerupuk Sebelum dan Sesudah Pelaksanaan Program Pengabdian

\begin{tabular}{clcc}
\hline No. & Uraian & Sebelum & Sesudah \\
\hline 1 & Volume adonan yang dibuat & $75 \mathrm{~kg}$ & $150 \mathrm{~kg}$ \\
2 & Frekuensi pembuatan adonan per minggu & $2 \mathrm{kali} / \mathrm{minggu}$ & $2 \mathrm{kali} / \mathrm{minggu}$ \\
3 & Kerupuk terjual per bulan & 930 bungkus & 1.860 bungkus \\
\hline
\end{tabular}

Tabel 1 merupakan kondisi produktivitas usaha kerupuk dalam kondisi cuaca yang kurang mendukung sebelum adanya oven pengering, sehingga dilakukan pengeringan kerupuk secara konvensional apabila memungkinkan. Sesudah adanya oven pengering, produktivitas rata-rata bertambah menjadi dua kali lipat dibandingkan dengan kondisi sebelum adanya oven pengering.

Alat pengering ini telah digunakan dan dioperasikan sendiri oleh mitra dan tidak ada kesulitan yang berarti dalam mengoperasikan alat ini. Secara umum, mitra dapat bekerja sama dengan baik selama proses perancangan, pembuatan, sampai dengan pengoperasian alat pengering kerupuk. Hal tersebut merupakan faktor pendukung dalam pelaksanaan kegiatan pengabdian masyarakat ini.

Dalam pengoperasian awal alat pengering ini terdapat sedikit kesulitan untuk menemukan bagaimana cara mengoperasikan alat pengering yang optimal. Beberapa kali percobaan awal tidak menghasilkan kerupuk seperti yang diharapkan, karena kerupuk yang masih basah tidak bisa langsung dikeringkan menggunakan oven pengering. Cara tersebut menghasilkan kerupuk yang gosong ketika digoreng, karena kerupuk masih belum cukup kering sampai ke bagian dalam kerupuk. Pengeringan menggunakan oven baru bisa dilakukan dengan hasil yang baik apabila kerupuk yang masih basah diangin-anginkan dahulu secukupnya sampai agak kering, baru kemudian dilanjutkan pengeringannya menggunakan oven. Hal ini merupakan faktor penghambat yang biasa terjadi dalam implementasi perangkat teknologi tepat guna.

Dengan menggunakan alat pengering, hal positif lain yang diperoleh adalah kerupuk hasil produksi mitra menjadi lebih bersih dibandingkan dengan apabila menggunakan pengeringan secara konvensional. Hal ini dikarenakan proses penjemuran kerupuk secara konvensional di halaman rumah mitra sangat memungkinkan terjadinya kontaminasi dengan debu atau partikel lain yang melayang di udara terutama ketika terjadi angin kencang. Pengeringan dengan cara diangin-anginkan di teras rumah yang dilanjutkan dengan pengeringan dengan oven menghasilkan kerupuk yang lebih bersih karena kerupuk relatif lebih tertutup selama proses pengeringan. Hal ini akan menambah nilai jual kerupuk, karena konsumen cenderung mengingat dan meninggalkan produk makanan olahan merk apa yang pernah mereka konsumsi dan ternyata bercampur dengan partikel yang tidak dikehendaki (Nugroho, 2012) [15].

Untuk mengukur sejauh mana kepuasan konsumen terhadap kerupuk hasil pengeringan menggunakan oven, dilakukan jajak pendapat masyarakat konsumen kerupuk oleh tim. Jajak pendapat ini menggunakan kuesioner seperti ditunjukkan dalam Tabel 2. Kuesioner ini membandingkan kerupuk yang dikeringkan dengan sinar matahari (Kerupuk A) dengan kerupuk yang dikeringkan oleh oven pengering (Kerupuk B). 
Tabel 2. Respons Konsumen Terhadap Kerupuk

\begin{tabular}{clcccc}
\hline No. & Pertanyaan & SS & S & TS & STS \\
\hline 1 & Saya suka dengan rasa dan kualitas krupuk A & 12 & & & \\
2 & Saya suka dengan rasa dan kualitas krupuk B & 11 & 1 & & \\
3 & Saya suka dengan tekstur krupuk A & 1 & 11 & & \\
4 & Saya suka dengan tekstur krupuk B & 10 & 2 & & \\
5 & Saya suka dengan kerenyahan kerupuk A & 3 & 8 & 1 & \\
6 & Saya suka dengan kerenyahan kerupuk B & 11 & 1 & & \\
7 & Kerupuk A sama renyahnya dengan kerupuk B & 1 & 3 & 6 & 3 \\
8 & Kualitas dan rasa kerupuk sama dengan kerupuk B & 6 & 2 & 1 & 3 \\
9 & Tekstur Kerupuk A sama dengan kerupuk B & 2 & & 6 & 4 \\
\hline
\end{tabular}

dengan Kerupuk A: dikeringkan dengan sinar matahari dan Kerupuk B: dikeringkan dengan oven pengering. SS berarti Sangat Suka, S berarti Suka, TS berarti Tidak Suka, dan STS berarti Sangat Tidak Suka.

Variabel yang diukur dalam jajak pendapat adalah mengenai kualitas dan rasa kerupuk, tekstur dan kerenyahan kerupuk serta sejauh mana kedekatan kualitas dari kerupuk B terhadap kerupuk A. Jumlah responden total adalah 12 orang, dengan respons keseluruhan ditunjukkan padaTabel 2. Dari data responden yang diterima, nampak bahwa kerupuk A maupun B sangat digemari oleh masyarakat, karena faktor kualitas dan rasa kerupuk tersebut. Namun mengenai tekstur kerupuk, kerupuk B ternyata lebih disukai oleh responden dari pada kerupuk A. Demikian juga kerupuk B ternyata lebih disukai karena lebih renyah dari pada kerupuk A.

Hal ini cukup menggembirakan karena pengering kerupuk menggunakan alat pengering dapat menghasilkan kerupuk yang lebih disukai dari pada kerupuk yang dikeringkan dengan cara konvensional.

Untuk mengukur perbedaan kualitas dan rasa, kerenyahan maupun tekstur kerupuk A dan kerupuk B, disertakan pertanyaan nomor 7, 8, dan 9 yang meminta responden membandingkan karateristik kerupuk A dan B pada kuesioner tersebut. Berdasarkan respons terhadap pertanyaan itu, dapat disimpulkan bahwa mayoritas responden menganggap bahwa kualitas dan rasa, kerenyahan, maupun tekstur kerupuk A dan kerupuk B berbeda.

\section{Kesimpulan}

Dengan menggunakan alat pengering ini, produktivitas kerupuk yang dibuat oleh mitra dapat ditingkatkan $100 \%$, khususnya selama musim penghujan. Cara penggunaan alat cukup sederhana, dapat dipahami dengan baik oleh mitra dan karyawannya sehingga alat tersebut telah dioperasikan sepenuhnya oleh mitra.

\section{Ucapan Terima Kasih}

Penulis mengucapkan terima kasih kepada Lembaga Penelitian dan Pengabdian Masyarakat (LPPM) Universitas Islam Malang atas dukungan finansial yang diberikan sehingga kegiatan ini dapat terlaksana.

\section{Daftar Pustaka}

[1] R. Wahyono, Pembuatan aneka kerupuk. Niaga Swadaya, 2003.

[2] F. K. Hartati, "Alternatif pengganti boraks pada pembuatan kerupuk puli," Heuristic, vol. 15, no. 02, 2018. 
[3] C. Sundaygara and R. N. I. Dinnullah, "Peningkatan Usaha UKM Kerupuk Puli Melalui Pelatihan dan Pendampingan Manajemen Pengemasan Produk," Abdimas Galuh, vol. 3, no. 2, pp. 255-264, 2021.

[4] E. Ernawati and I. L. Fuad, "IbM TEKNOLOGI PEMBUATAN PULI LELE SEHAT UNTUK MENINGKATKAN PENDAPATAN RUMAH TANGGA IBU PKK DI DESA WONOREJO PASURUAN,” SKETSA BISNIS, vol. 3, no. 2, pp. 32-38, 2016.

[5] J. Sirait, "Pembuatan Alat Pengering Kerupuk Rambak dengan Kapasitas 30 Kg," J. Ris. Teknol. Ind., vol. 7, no. 14, pp. 118-125, 2016.

[6] R. J. Espito \& Thrower, “Machine Design Vacuum Frying.” NewYork: delmar Publisher, Inc, 1991.

[7] S. Syafriyudin and D. P. Purwanto, "Oven pengering kerupuk berbasis mikrokontroler ATmega 8535 menggunakan pemanas pada industri rumah tangga,” J. Teknol., vol. 2, no. 1, pp. 70-79, 2009.

[8] R. P. Fajri, M. Maimuzar, and R. Sumiati, “Alat Pengering Kerupuk Palembang Dengan Menggunakan Gas LPG,” J. Tek. Mesin, vol. 10, no. 2, pp. 31-37, 2017.

[9] H. Wibowo and E. Purnomo, "Pembuatan Alat Pengering Kerupuk Untuk Industri Kecil Pedesaan," INOTEKS, vol. 8, no. 2, 2004.

[10] E. A. Kuncoro, "DESAIN SISTEM PENGERING KERUPUK KEMPLANG DENGAN UAP SUPER PANAS BERBAHAN BAKAR BIOMASA,” BUANA SAINS, vol. 14, no. 2, pp. 29-36, 2014.

[11] A. S. Nugroho and A. T. Rahayu, "Pemberdayaan Masyarakat Desa Gawan dalam Rangka Peningkatan Usaha Makanan Intip Beras,” JURPIKAT (Jurnal Pengabdi. Kpd. Masyarakat), vol. 1, no. 2, pp. 168-177, 2020.

[12] B. Maharani and S. P. D. Sofianti, "Ipteks bagi Masyarakat Perajin Kerupuk Puli di Lingkungan Gumuk Kerang Kelurahan Sumbersari Kabupaten Jember,” 2015.

[13] D. T. Rudianto and N. Ahmadi, "Rancang bangun turbin angin savonius 200 watt," in Seminar Nasional Teknologi Informasi dan Kedirgantaraan (SENATIK), 2016, vol. 2, pp. 71-75.

[14] A. S. Nugrooho and A. T. Rahayu, "PENGABDIAN PADA MASYARAKAT: SOLUSI UKM INTIP DALAM MENINGKATKAN PRODUKSI SAAT MUSIM HUJAN,” 2020.

[15] A. Nugroho, "Pengaruh Kualitas Lingkungan Fisik, Kualitas Makanan, Kualitas Pelayanan Pada Restaurant Image, Perceived Value, Kepuasan Konsumen, Dan Behavioral Intention (Studi Kasus Pada Kfc Dan Hoka-Hoka Bento Di Solo Square Surakarta),” 2012.

\author{
Afiliasi: \\ Unung Lesmanah*, M. Jasa Afroni, Abdul Wafi \\ Universitas Islam Malang \\ Jln. MT. Haryono 193 Malang, Jln. MT. Haryono 193 Malang, Jln. MT. Haryono 193 Malang \\ Email: email.ununglesmanah@unisma.ac.id*, jasa.afroni@unisma.ac.id, \\ abdulwafi@unisma.ac.id
}

